\title{
Total Reflection X-Ray Fluorescence Analysis of Toxic Metals in Fish Tissues
}

\author{
Graciela Zarazúa ${ }^{1 *}$, Karina Girón-Romero², Samuel Tejeda1, Carmen Carreño-De León33, \\ Pedro Ávila-Pérez ${ }^{1}$ \\ ${ }^{1}$ Nuclear Technology Division, National Institute for Nuclear Research, Ocoyoacac, Mexico \\ ${ }^{2}$ Faculty of Science, University of Mexico State, Tlachaloya, Mexico \\ ${ }^{3}$ Technology Institute of Toluca, Metepec, Mexico \\ Email: *graciela.zarazua@inin.gob.mx
}

Received 25 June 2014; revised 13 August 2014; accepted 29 August 2014

Copyright (C) 2014 by authors and Scientific Research Publishing Inc.

This work is licensed under the Creative Commons Attribution International License (CC BY). http://creativecommons.org/licenses/by/4.0/

(c) (i) Open Access

\section{Abstract}

The concentration of $\mathrm{Cr}, \mathrm{Ni}, \mathrm{Cu}, \mathrm{Zn}, \mathrm{Hg}$ and $\mathrm{Pb}$, considered like toxic, was evaluated in fish tissues by means the total reflection X-Ray Fluorescence technique (TXRF). Grass carp (Ctenopharygodon idella) samples were collected from six regions of the Tepuxtepec Dam which was used as a water reservoir and fish production for the local population. Fish tissues: gills, liver, kidney and muscle were analyzed in triplicate using a TXRF spectrometer "TX-2000 Ital Structures" with a Si(Li) detector and a resolution of $140 \mathrm{eV}$ (FWHM) at $\mathrm{Mn} \mathrm{K \alpha}$ and Mo tube $(40 \mathrm{kV}, 30 \mathrm{~mA})$ with $17.4 \mathrm{KeV}$ excitation energy. The mean concentration of metals in tissues decrease in the sequence: Kidney $\approx$ Gills > Liver > Muscle; the range of concentration for $\mathrm{Zn}$ was $26.68-816.67 \mathrm{mg} / \mathrm{Kg}$ followed by Cu: $1.18-35.81 \mathrm{mg} / \mathrm{Kg}$, Cr: $1.10-9.30 \mathrm{mg} / \mathrm{Kg}$, Ni: $0.40-3.80 \mathrm{mg} / \mathrm{Kg}, \mathrm{Pb}:<0.02-1.92 \mathrm{mg} / \mathrm{Kg}$ and $\mathrm{Hg}$ : $<0.03-1.97 \mathrm{mg} / \mathrm{Kg}$. Chromium and mercury concentrations slightly exceed the limits for fish proposed by FAO/WHO and Mexican Legislation for human consumption in the edible parts of fish from each one of the regions of the Tepuxtepec Dam. The results show that metal accumulation in herbivorous carp tissues was higher in regions 1,2 and 3 than the others, which could be due to the influence of Lerma River, one of the most polluted rivers of Mexico.

\section{Keywords}

Metals, Fish Tissues, TXRF

\footnotetext{
${ }^{*}$ Corresponding author.
}

How to cite this paper: Zarazúa, G., Girón-Romero, K., Tejeda, S., León, C.C.-D. and Ávila-Pérez, P. (2014) Total Reflection X-Ray Fluorescence Analysis of Toxic Metals in Fish Tissues. American Journal of Analytical Chemistry, 5, $805-811$. 


\section{Introduction}

Different kinds of contaminants from agricultural, domestic and industrial sources are increasingly being released into different water bodies and can modify their water quality so it is unsuitable for different purposes such as irrigation, aquaculture, recreation, human consumption, etc. [1]. The pollution of the aquatic ecosystems with heavy metals has become a worldwide problem because they are persistent and can produce a range of toxic effects in aquatic organisms [2]. Fishes are often at the top of the aquatic food chain and may concentrate large amounts of some metals from the water [3]. Furthermore, fish is one of the most indicative factors in freshwater systems, for the estimation of trace metal pollution and risk potential of human consumption [4]. Heavy metals are taken up through different organs of the fish because of the affinity between them. In this process, many of these heavy metals are concentrating at different levels in different organs at the fish body [5]. Hence, it is important to determine the concentrations of heavy metals in commercial fishes in order to evaluate the possible risk of fish consumption.

The grass carp (Ctenopharyngodon idella) is an herbivorous, freshwater fish species of family Cyprinidae, and the only species of the genus Ctenopharyngodon. It feeds on a wide range of aquatic vegetation, and is capable of consuming 40\% - 300\% of their body mass per day of plant material depending on their age and size. Fry consume planktonic crustaceans, rotifers, and insect larvae, while adults are completely vegetarian. Grass carpare used worldwide for control of aquatic vegetation as well as an important food fish [6].

The aim of this study was to evaluate the concentration of $\mathrm{Cr}, \mathrm{Cu}, \mathrm{Zn}, \mathrm{Hg}$ and $\mathrm{Pb}$ in gills, liver, kidney and muscle of grass carp (Ctenopharygodon idella) from Tepuxtepec Dam, Michoacán. This body water is supplied mainly by the Lerma River, which is receiving municipal wastewater, agricultural and industrial discharges, this water contains a large amount of organic and inorganic contaminants that enter the body of water in contact with the biota [7]. Finally, the results obtained were compared with the permissible limits (MPL) established by current Mexican law and the FAO/WHO [8] [9].

\section{Material and Methods}

\subsection{Study Area}

The Tepuxtepec dam, giving rise to the Middle Basin of the Lerma River, is situated in the State of Michoacán, Mexico (20 $02^{\prime}$ north latitude and $100^{\circ} 13^{\prime}$ west longitude) (Figure 1). It has a storage capacity of $585 \mathrm{~h} \cdot \mathrm{m}^{3}$ in 57 $\mathrm{km}^{2}$ is the eighth dam water uptake capacity in the State of Michoacán. This reservoir was built for the purpose of generating energy through hydroelectric Lerma and control of Lerma River floods and as a secondary activity is done growing grass carp (Ctenopharygodon idella), under an extensive production system, which depend approximately 230 families who are organized in 6 regions of production and marketing [10].

\subsection{Sampling Collection}

In this study 60 grass carp were collected at six production regions in the Tepuxtepec Dam (Figure 1). Ten specimens were randomly sampled in all regions. Grass carp samples were labeled, store on ice and the same day transported to the laboratory for further treatment and analysis.

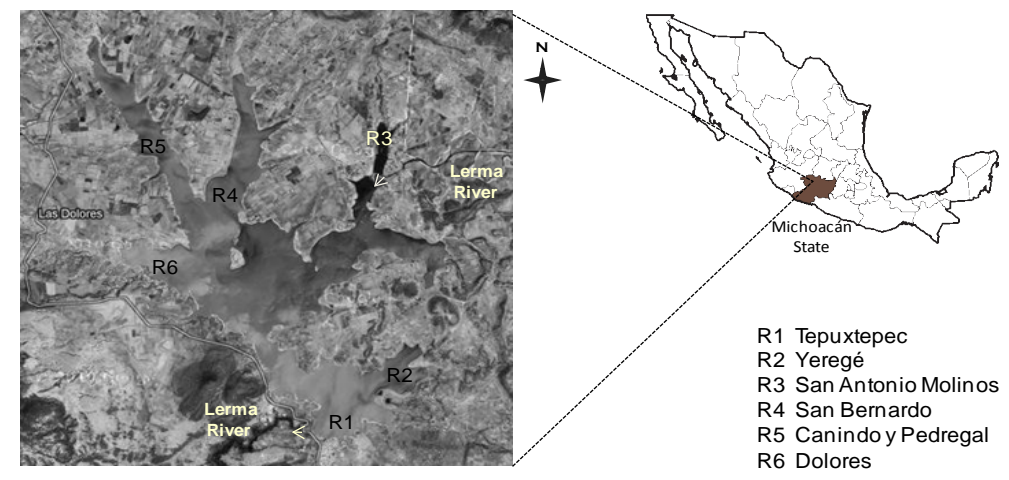

Figure 1. Localization of the Tepuxtepec Dam, Michoacán, Mexico and sampling regions of grass carp (Ctenopharygodon idella). 


\subsection{Sample Preparation}

The grass carp samples were dissected to separate tissues (gills, liver, kidney and muscle) according to FAO methods [11]. Tissues samples were washed thoroughly in running tap water to avoid any surface contamination and then rinsed with de-ionized water. The cleaned grass carp tissues were freeze-dried, ground, sifted to 200 mesh and homogenized. $0.5 \mathrm{~g}$ subsample of each region was putted in a closed digestion vessel and digested in a microwave oven (Mars-X, CEM Corporation) according to the 5BI-8 method for "Fish tissue". The digested sample was transferred into a volumetric flask, the reaction vessels were washed out with de-ionized water and the flask volume made up to a final volume of $25 \mathrm{~mL}$. $100 \mu \mathrm{L}$ of Yttrium standard solution (Merck) of 10 $\mathrm{mg} / \mathrm{mL}$ was added as internal standard to $1 \mathrm{~mL}$ subsample of the digested samples and mixed. After that, $20 \mu \mathrm{L}$ of the digested tissue sample was deposited on a silicon quartz glass holder [12]. Only supra pure grade quality chemicals were used.

\subsection{Sample Analysis}

$\mathrm{X}$ Ray Fluorescence is a nuclear analytical technique which has the advantage to be multi-elemental, fast and economical. The TX 2000 X-Ray Spectrometer manufactured by Ital Structures was used in order to obtain the elemental concentration. A primary fine focus beam provided by the X-Ray tube with a molybdenum anode is monochromatised and is directed to the sample at a glancing angle less than the critical angle. The tube was operated at $40 \mathrm{kV}$ and $30 \mathrm{~mA}$. The fluorescent X-Rays derived from the sample were detected with a solid state lithium-drifted silicon detector of $20 \mathrm{~mm}^{2}$ front area, cooled with liquid nitrogen. The energy resolution (FWHM) of the $\mathrm{Si}(\mathrm{Li})$ detector was $140 \mathrm{eV}$ for $\mathrm{Mn} \mathrm{K} \alpha$ and its beryllium window was $8 \mu \mathrm{m}$ thick.

Three replicates were prepared for each sample in order to evaluate the reproducibility of measurements. All samples were excited for $500 \mathrm{~s}$. Heavy metal concentration and detection limits were determined by means of the software "EDXRF32-Ital Structures" using the theoretical "Sensitivities with internal standard" method. It is based on the sensitivity values of the different elements. For the analysis of the spectra and metal quantification, the software EDXRF32 was used [13]. Detection limit (DL) listed in Table 1 were calculated with the Equation (1) [14]:

$$
D L=3(C x / I x)(\sqrt{2} I B G)
$$

where $D L$ : Detection limit (minimum detectable mass mg/Kg); $C x$ : Analyte concentration (mg/Kg); $I x$ : Analyte net intensity (counts) and IBG: Background intensity (counts).

\subsection{Statistical Analysis}

Data were processed by the Statgraphics Plus 5 program in order to obtain the average values, standard deviations and confidence limits. The Statgraphics software allowed investigation of the existence of a normal distribution for the data values. The analysis of variance (ANOVA) was applied to data values when normal distribution was observed, and the Kruskal-Wallis test was used when no normal distribution law was observed, in order to deduce spatial distributions for heavy metals in the Tepuxtepec Dam. The statistical methods were performed with a $95 \%$ confidence interval $(\mathrm{CI} ; \alpha=0.05)$.

Table 1. Comparison between measured and certified elements concentration for the reference material IAEA MA-A-1 (TM) Copepod homogenate.

\begin{tabular}{ccccccc}
\hline & \multicolumn{2}{c}{ Certified values } & \multicolumn{2}{c}{ Measured values } & RE & DL \\
\hline \multirow{2}{*}{ Element } & Mean concentration & SD & Mean concentration & SD & $\%$ & $\mathrm{mg} / \mathrm{kg}$ \\
\cline { 2 - 6 } & 1.1 & 0.20 & 1.05 & 0.06 & 95 & 0.05 \\
$\mathrm{Cr}$ & 1.9 & 0.20 & 2.02 & 0.16 & 106 & 0.04 \\
$\mathrm{Ni}$ & 7.6 & 0.20 & 7.20 & 0.36 & 95 & 0.02 \\
$\mathrm{Cu}$ & 158 & 2.00 & 166 & 8 & 105 & 0.02 \\
$\mathrm{Zn}$ & 0.28 & 0.01 & 0.26 & 0.02 & 93 & 0.05 \\
$\mathrm{Hg}$ & 2.1 & 0.30 & 2.05 & 0.08 & 97 & 0.03 \\
$\mathrm{~Pb}$ & & & & & & \\
\hline
\end{tabular}

SD: Standard deviation; RE: Recovery; DL: Detection limit. 


\section{Results and Discussion}

In order to evaluate the accuracy and reproducibility of the analytical results, three sub-samples of the reference material "IAEA MA-A-1 (TM): Copepod homogenate” from the International Atomic Energy Agency (IAEA) were analyzed. The elemental concentrations in the samples are shown in Table 1 . As it can be seen, the measured concentrations were consistent with the certified values. Accuracy being measured as the percentage of recoveries (\% RE) after the acid digestion (ratio between values measured and certified in the reference material), was higher than $93 \%$ and the percentage relative error was from lower than $2 \%$ to $13 \%$. Detection limits (DL) for the experimental conditions are also shown.

Maximum, minimum and mean concentration, of the analysed metals in the grass carp tissues are given in the Table 2. Concentrations of $\mathrm{Cr}, \mathrm{Ni}, \mathrm{Cu}, \mathrm{Zn}, \mathrm{Hg}$ and $\mathrm{Pb}$, considered like toxic metals in aquatic environment, varied between $<0.03$ and $817 \mathrm{mg} / \mathrm{Kg}$, being highest for the zinc and lowest for the mercury and lead.

Analyzing the results it is observed that zinc presented the highest concentration followed $\mathrm{Cu}, \mathrm{Cr}, \mathrm{Ni}, \mathrm{Pb}$ and Hg. The results confirm the differences of heavy metal accumulation in the different tissues. In this study heavy metal accumulation order was, Kidney > Gills > Liver > Muscle. On the other hand, target organs, such as liver, gonads, kidney and gills, are metabolically active tissues and accumulate heavy metals of higher levels, as was observed many experimental and field studies [15] [16], in this study it was found that kidney and gills were the main accumulators of $\mathrm{Ni}, \mathrm{Zn}$ and $\mathrm{Pb}$; $\mathrm{Cr}$ is accumulates in liver and kidney; $\mathrm{Cu}$ is accumulates mainly in liver while Hg goes to gills and muscle (Figure 2).

Table 2. Content of $\mathrm{Cr}, \mathrm{Ni}, \mathrm{Cu}, \mathrm{Zn}, \mathrm{Hg}$ and $\mathrm{Pb}$ in grass carp (Ctenopharygodon idella) tissues from Tepuxtepec Dam. Concentration in $\mathrm{mg} / \mathrm{Kg}$.

\begin{tabular}{|c|c|c|c|c|c|c|c|}
\hline Fish tissue & & $\mathrm{Cr}$ & $\mathrm{Ni}$ & $\mathrm{Cu}$ & $\mathrm{Zn}$ & $\mathrm{Hg}$ & $\mathrm{Pb}$ \\
\hline \multirow[t]{3}{*}{ Gills } & Minimum value & 1.9 & 1.3 & 2.1 & 338 & 1.07 & 1.06 \\
\hline & Maximum value & 4.7 & 2.6 & 4.2 & 817 & 1.18 & 2.06 \\
\hline & Mean & 3.0 & 2.0 & 2.8 & 572 & 1.13 & 1.47 \\
\hline \multirow[t]{3}{*}{ Liver } & Minimum value & 1.4 & 0.3 & 23.2 & 204 & $<0.05$ & $<0.03$ \\
\hline & Maximum value & 8.5 & 1.8 & 38.7 & 468 & $<0.05$ & $<0.03$ \\
\hline & Mean & 3.8 & 1.0 & 30.9 & 304 & $<0.05$ & $<0.03$ \\
\hline \multirow[t]{3}{*}{ Kidney } & Minimum value & 1.1 & 0.2 & 5.7 & 499 & $<0.05$ & 1.01 \\
\hline & Maximum value & 9.3 & 4.1 & 7.6 & 728 & $<0.05$ & 1.92 \\
\hline & Mean & 3.9 & 2.0 & 6.7 & 596 & $<0.05$ & 1.30 \\
\hline \multirow[t]{3}{*}{ Muscle } & Minimum value & 1.3 & 1.3 & 1.7 & 27 & 0.63 & $<0.03$ \\
\hline & Maximum value & 1.9 & 2.5 & 5.2 & 36 & 1.95 & $<0.03$ \\
\hline & Mean & 1.6 & 1.7 & 2.6 & 30 & 1.40 & $<0.03$ \\
\hline MPL $_{\text {muscle }}$ FAO (FAO/WHO, 2004) & & 1.0 & NR & 10 & 50 & 1.0 & 1.0 \\
\hline MPL $_{\text {muscle }}$ SS (SS, 1995) & & NR & NR & NR & NR & 1.0 & 1.0 \\
\hline $\begin{array}{c}\text { Rate: Mean muscle } \\
\text { value/MPL } \\
\text { muscle } F A O, \text { SS value }\end{array}$ & & 1.6 & NA & 0.26 & 0.6 & 1.4 & $<0.03$ \\
\hline
\end{tabular}

MPL: Maximum permissible limit, NR: Not reported, NA: Not applicable; FAO/WHO, (2004) Comission of Codex Alimentarius. ALINORM 04/27/18; SS, Health Department (1995). NOM: Official Mexican Norm. NOM-027-SSA1-1995. 

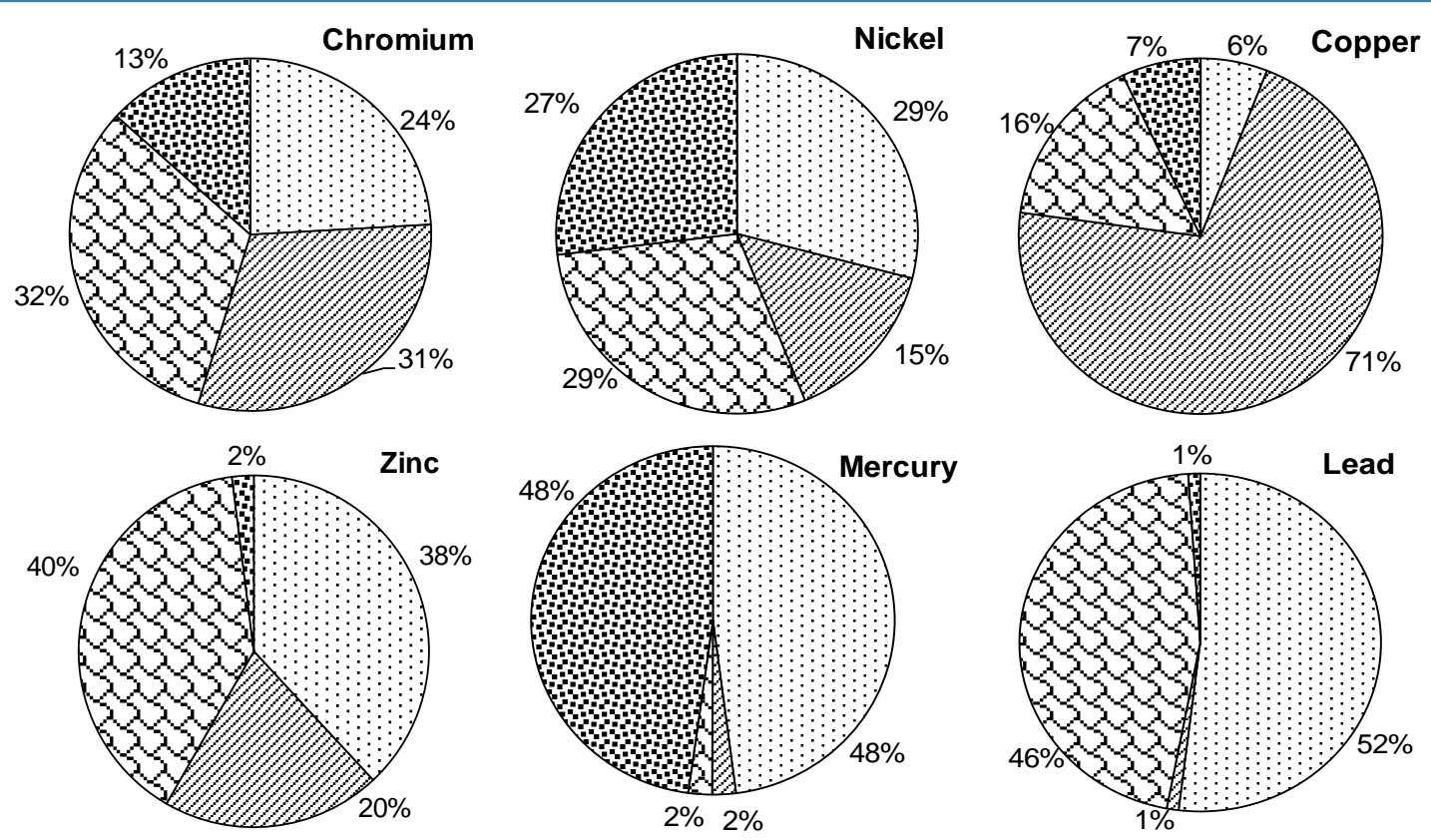

Gills $\dddot{Z}$ Liver Kidney Muscle

Figure 2. Distribution of $\mathrm{Cr}, \mathrm{Ni}, \mathrm{Cu}, \mathrm{Zn}, \mathrm{Hg}$ and $\mathrm{Pb}$ in grass carp (Ctenopharygodon idella) tissues from tepuxtepec dam.

The high accumulation of Zn could certainly be based on specific metabolism process and coenzyme catalyzed reactions involving zinc taking placed in kidney [17]. Zinc also acts as a catalyst in metal biomolecules bound to aminoacids side chains containing $\mathrm{N}, \mathrm{O}$ and/or sulfur donor legends to form tetrahedral zinc metalloproteins and metalloenzymes in kidney tissue [18] [19].

The liver is often considered a good monitor of water pollution with metals since their concentrations are proportional to those present in the aquatic environment. Liver is a target organ of accumulation for many metals, because of its strong irrigation and excretion function. The liver tissue is highly active in the uptake and storage of heavy metals. It is well known that large amount of metallothionein induction occurs in the liver tissue of fishes [20].

The gills constitute a multifunctional organ (respiration, ion and acid-base regulation, nitrogenous waste excretion, etc.) accounting for over $50 \%$ of the total surface area of the animal. Gills are uptake site of waterborne ions, where metal concentrations increase especially at the beginning of exposure, before the metal enters other parts of organism, the reason for high metal concentrations in the gills could be due to the metal complexing with the mucus that is impossible to remove completely from the lamellae before analysis [20].

Many studies reported that on a number of fish species, which show that muscle is not an active tissue in accumulating heavy metals [15] [21]-[23]. Heavy metal analysis in edible parts (muscle) indicated that, only $\mathrm{Hg}$ and $\mathrm{Cr}$ were higher than the limits for human consumption in edible parts; however, the monitoring of other metals is important because they are considered toxic to humans and also by the influence of wastewater discharges could exceed the limits for human consumption in edible parts [8] [9].

Furthermore the accumulation of heavy metals in fishes may induce changes in biochemical metabolism and other induced stress: lead and mercury belong to the group of non-essential and toxic metals, implying no known function in biochemical processes; copper and zinc are both micro-nutrient and toxicant, however $\mathrm{Zn}$ is about five-fold less toxic than $\mathrm{Cu}$, and $\mathrm{Zn}$ uptake at the gills appears to be a normal branchial function occurring via the chloride cells The gills are an important site for the entry of heavy metals that provokes lesions and gill damage while higher accumulation in liver may alter the levels of various biochemical parameters causing severe liver damage [15].

Figure 3 shows the metal concentrations by sampling region obtained in this work, in general the element concentrations in the fish tissues were found to decrease in the sequence: R3 $>$ R1 $>$ R2 $>$ R4 $>$ R6 $>$ R5. Statistical differences $(\alpha \leq 0.05)$ in the metal concentrations, between samples taken in the sampling regions 1,2 and 


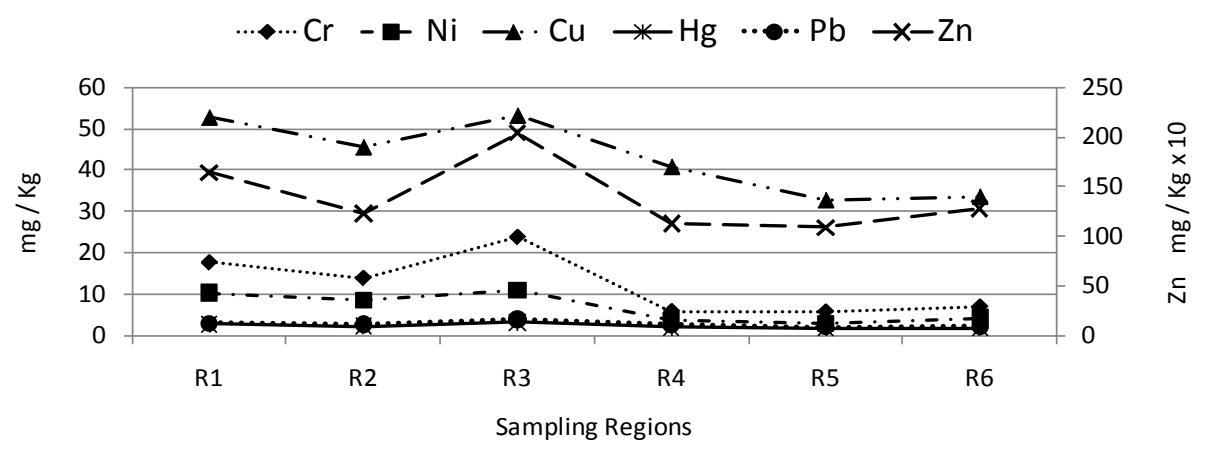

Figure 3. Sum of metal concentration in fish production regions from tepuxtepec dam. Concentration in $\mathrm{mg} / \mathrm{kg}$.

3 (spatial variation) were observed respect to the others.

It is general accepted that heavy metal uptake occurs mainly from water, food and sediment however, the efficiency of metal uptake from contaminated water and food may differ in relation to ecological needs, metabolism, and the contamination gradients of water, food and sediment as well as other factors such as age, weight, $\mathrm{pH}$, temperature, etc. [24].

The presence of metals in this body of water is influenced by the contribution of the Lerma River, which is the main tributary, it presents a high degree of contamination by metals and on the other hand, metals such as $\mathrm{Cu}$, $\mathrm{Zn}$ and $\mathrm{Hg}$ can be from agricultural runoff, therefore the high levels of metal in fish tissues from sampling regions 1, 2 and 3 may be due to these fish production regions are closer to the inner course Lerma River.

\section{Conclusions}

The accumulation of toxic metals varied among grass carp (Ctenopharyngodon idella) tissues. Results showed that metal accumulation in the gills, liver and kidney was higher than in muscle, except for mercury.

The concentration of $\mathrm{Hg}$ and $\mathrm{Cr}$ in muscle, edible tissue, exceeded slightly the maximum permissible limit established by the FAO/WHO and the Mexican Legislation and could pose a health risk to consumers of grass carp from Tepuxtepec Dam.

Higher accumulation of metals in the gills, liver and kidney may be considered a primary signal of metal exposure and can be affect the aquatic life of the fresh water fish.

Heavy metals accumulate mainly in metabolic organs, such as liver and kidney and can be provokes damage in the grass carp (Ctenopharyngodon idella) metabolism.

Most of the data concentrations in the fish tissues of the sampling regions 3, 1 and 2 were higher than concentrations in the other four sampling regions due to the contribution of the Lerma River.

TXRF was used to measure a toxic metal in fish tissues, which had the ability to accumulate them and therefore could be used as a tool for future monitoring programs, to evaluate the metal pollution of the Tepuxtepec Dam.

The accuracy related to the sample preparation and the measurement with the TXRF equipment was very good, which was demonstrated by the use of the standard reference material. In relation to the reproducibility, the results show a very good standard deviation.

The Total Reflection X-ray Fluorescence Spectrometry applied to biomonitoring and toxicology studies offers reliable information about elements considered like toxic by the aquatic life.

\section{References}

[1] Tejeda, S., Ávila-Pérez, P. and Zarazúa, G. (2011) Evaluación del índice de la calidad de agua en el curso alto del río Lerma. In: Bedregal, P., Ed., Propuesta de un índice de calidad de agua para la región de Latinoamérica y el Caribe, Peru, 147-164.

[2] Fatima, M. and Usmani, N. (2013) Histopathology and Bioaccumulation of Heavy Metals (Cr, Ni and Pb) in Fish (Channa striatus and Heteropneustes fossilis) Tissue: A Study for Toxicity and Ecological Impacts. Pakistan Journal of Biological Sciences, 16, 412-420. http://dx.doi.org/10.3923/pjbs.2013.412.420

[3] Mansour, S. and Sidky, M. (2002) Ecotoxicological Studies. 3. Heavy Metals Contaminating Water and Fish from 
Fayoum Governorate Egypt. Food Chemistry, 78, 15-22. http://dx.doi.org/10.1016/S0308-8146(01)00197-2

[4] Papagiannis, I., Kagalou, I., Leonardos, J., Petridis, D. and Kalfakaou, V. (2004) Copper and Zinc in Four Freshwater Fish Species from Lake Pamvotis (Greece). Environment International, 30, 357-362. http://dx.doi.org/10.1016/j.envint.2003.08.002

[5] Rao, L. and Padmaja, G. (2000) Bioaccumulation of Heavy Metals in M. cyprinoids from the Harbor Waters of Visakhapatnamu. Bulletin Applied Science, 19, 77-85.

[6] Lloyd, R. (2003) Pollution and Freshwater Fish. Fishing New Books Ed., Oxford.

[7] Ávila-Pérez, P., Zarazúa, G., Carapia-Morales, L., Tejeda, S., Barceló-Quintal, I. and Martínez, T. (2011) Concentration of Elements in Suspended Matter Discharges to Lerma River, Mexico. Journal of Radioanalytical and NuclearChemistry, 287, 383-391. http://dx.doi.org/10.1007/s10967-010-0887-8

[8] FAO/WHO, Comission of Codex Alimentarius (2004) Programa Conjunto FAO/OMS Sobre Normas Alimentarias ALINORM 04/27/18. Pescado y Productos Pesqueros, Roma.

[9] SS: Secretaría de Salud, Bienes y Servicios (1995) Productos de la pesca. Pescados frescos, refrigerados y congelados. Norma Oficial Mexicana NOM-O27-SSA1-1993.

[10] SEMARNAT: Secretaría del Medio Ambiente y Recursos Naturales (2006) Acuerdo por el que se da a conocer el estudio técnico de los recursos hídricos del área geográfica Lerma-Chapala. Diario Oficial de la Federación, 24 Julio, México.

[11] Dybem, B. (1993) Field Sampling and Preparation Subsamples of Aquatic Organism for Analysis Metals and Organochlorides, FAO. Fishery Technology, 212, 1-13.

[12] Deutsches Institut für Normung E.V. (2001) Total Reflection X-Ray Fluorescence Analysis (TXRF). German Norm: E DIN 51003:2001-01.

[13] Ital-Structures (2000) TX-2000 Spectrometer: Guide to the User, Italy.

[14] Klockenkämper, R. (1997) Total-Reflection X-Ray Fluorescence Analysis. Wiley, New York.

[15] Vinodhini, R. and Narayanan, M. (2008) Bioaccumulation of Heavy Metals in Organs of Fresh Water Fish Cyprinus carpio (Common Carp). International Journal of Environmental Science and Technology, 5, 179-182. http://dx.doi.org/10.1007/BF03326011

[16] Hogstrand, C. and Haux, C. (1991) Binding and Detoxification of Heavy Metals in Lower Vertebrates with Reference to Metallothionein. Comparative Biochemistry and Physiology Part C: Comparative Pharmacology, 100, 137-141. http://dx.doi.org/10.1016/0742-8413(91)90140-O

[17] Jaffar, J. and Pervaiz, S. (1989) Investigation of Multiorgan Heavy Trace Metal Content of Meat of Selected Dairy, Poultry, Fowl and Fish Species Pakistan. Journal of Scientific and Industrial Research, 32, 175-177.

[18] Shriver, D.F., Atkins, P.W. and Longford, C.H. (1989) Inorganic Chemistry. Oxford University Press, Oxford.

[19] Kendrick, M.H., Moy, M.T., Plishka, M.J. and Robinson, K.D. (1992) Metals and Biological Systems. Ellis Horwood Ltd., Chichester.

[20] Heath, A.G. (1987) Water Pollution and Fish Physiology. CRC Press, Boca Raton.

[21] Sen, I., Shandil, A. and Shrivastava, V.S. (2012) Study for Determination of Heavy Metals in Fish Species of the River Yamuna (Delhi) by Inductively Coupled Plasma-Optical Emission Spectroscopy (ICP-OES). Advances in Applied Science Research, 2, 161-166.

[22] Agatha, N. (2011) Levels of Some Heavy Metals in Tissues of Bonga Fish, Ethmallosa fimbriata (Bowdich, 1825) from Forcados River. Journal of Applied Environmental and Biological Sciences, 1, 44-47.

[23] Yacoub, A.M. and Gad, N.S. (2012) Accumulation of Some Heavy Metals and Biochemical Alterations in Muscles of Oreochromis niloticus from the River Nile in Upper Egypt. International Journal of Environmental Science and Technology, 3, 1-10. http://www.pvamu.edu/texged

[24] Pagenkopf, G.K. (1983) Gill Surface Interaction Model for Trace Metal Toxicity of Fish. Role of Complexation, pH, Water Hardness. Environmental Science and Technology, 17, 342-347. 
Scientific Research Publishing (SCIRP) is one of the largest Open Access journal publishers. It is currently publishing more than 200 open access, online, peer-reviewed journals covering a wide range of academic disciplines. SCIRP serves the worldwide academic communities and contributes to the progress and application of science with its publication.

Other selected journals from SCIRP are listed as below. Submit your manuscript to us via either submit@scirp.org or Online Submission Portal.
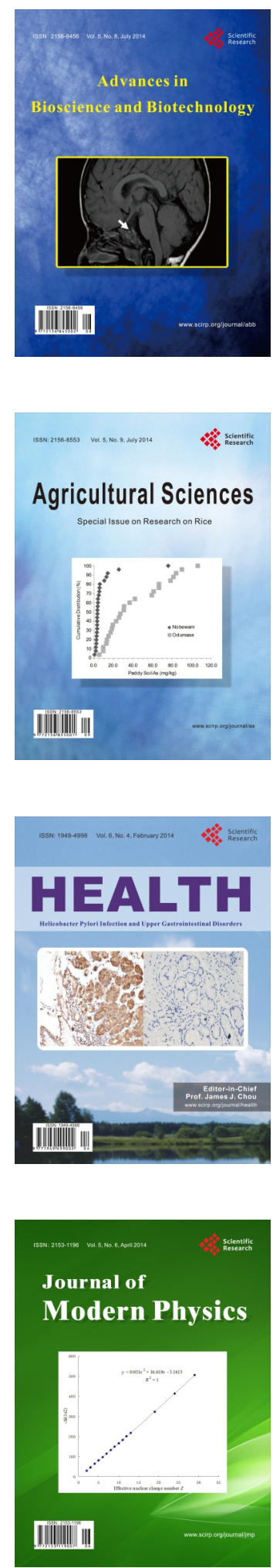
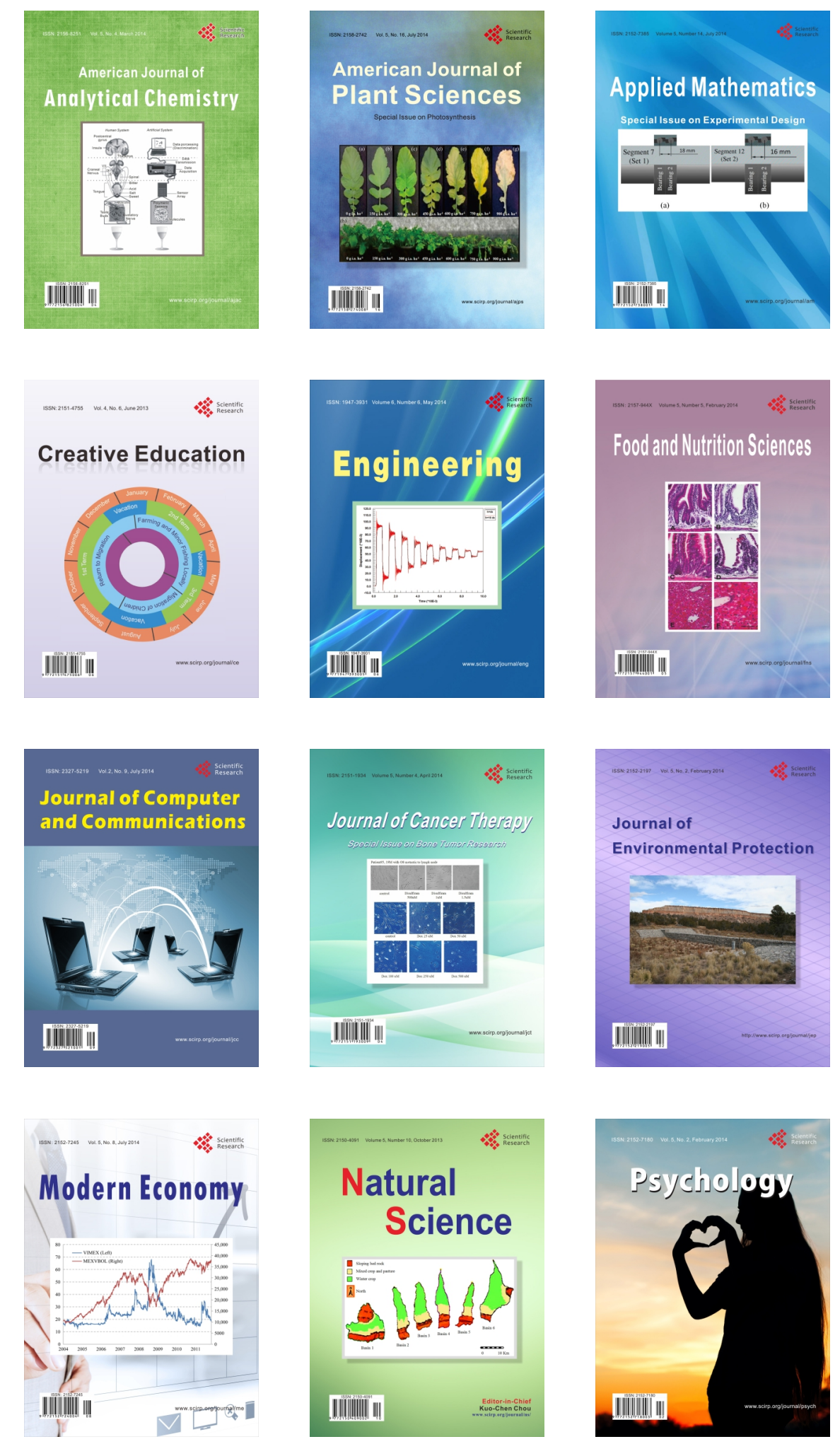